\title{
Penggunaan magic dalam politik lokal di Banten
}

\section{The use of magic in local politics of Banten}

\author{
Ayatullah Humaeni \\ Fakultas Ushuluddin, Dakwah dan Adab IAIN “Sultan Maulana Hasanuddin” Banten. \\ Jalan Jendral Sudirman 30 Ciceri Serang Banten 42118, Indonesia. Telepon: 081911036305. \\ E-mail: ayataditya@yahoo.com
}

\begin{abstract}
Village-head elections frequently become unhealthy competitions among the candidate. They employ various ways to win the election, including using magical means. This article aims to explain social phenomena occur in local politics in the use of magic village-head elections in rural Banten; particularly in two sub-districts, Ciomas and Padarincang. It tries to answer several main research questions: (1) why do the candidates make use of magic during the village election process?; (2) what kinds of magic used by the candidates; (3) How does magic influence the winning chance of village head elections? (4) and how is the process of the magic usage during the village election process?. This article is the result of a field research using ethnographical method based on anthropological perspective. To analyze the data, the researcher uses structural-functional approach. Library research, participant-observation, and depth-interview are methods used to collect the data. Based on the result of field research, it can be concluded that almost all of the candidates in these two sub-districts made use of magic in order to win the village head elections. They visit several magicians and made use of their super natural powers for their own purposes. They believed that magical power possessed by these magicians could influence their winning chance in the village-head elections. Various fundamental reasons also become an important consideration why the candidates need to use magic in local politics process.
\end{abstract}

Keywords: magic, local politics, village-head elections, Banten

\begin{abstract}
Abstrak
Pemilihan kepala desa seringkali menjadi ajang kompetisi yang tidak sehat di antara calon kepala desa. Mereka menggunakan berbagai cara untuk memenangkan pemilihan. Salah satunya menggunakan cara-cara magis. Artikel ini bertujuan menjelaskan fenomena sosial yang terjadi pada politik lokal di Banten yang difokuskan pada penggunaan magis dalam proses pemilihan kepala desa di pedesaan Banten, khususnya di Kecamatan Ciomas dan Kecamatan Padarincang. Oleh karena itu, penelitian ini akan menjawab beberapa rumusan masalah sebagai berikut: Mengapa calon kepala desa memanfaatkan magic dalam proses pemilihan kepala desa? Jenis magis apa saja yang digunakan oleh para calon kepala desa dalam proses pemilihan? Bagaimana proses pemanfaatan magis dalam proses pemilihan kepala desa? Artikel ini merupakan hasil penelitian lapangan dengan menggunakan metode etnografi yang bersifat deskriptif kualitatif dengan pendekatan antropologis. Dalam menganalisis data, peneliti menggunakan pendekatan fungsional-struktural. Metode yanga digunakan untuk mengumpulkan data adalah kajian pustaka, observasi, dan wawancara mendalam. Dari hasil penelitian, dapat disimpulkan bahwa hampir seluruh calon kepala desa di Kecamatan Ciomas dan Padarincang memanfaatkan magis untuk kepentingan pemenangan Pilkades. Mereka mendatangi para ahli magic dan memanfaatkan kemampuan magic para ahli magic ini untuk tujuan praktis mereka. Mereka yakin bahwa kekuatan magis dapat mempengaruhi proses pemenangan Pilkades. Berbagai alasan mendasar menjadi pertimbangan penting mengapa mereka harus memanfaatkan magis dalam proses politik lokal ini.
\end{abstract}

Kata kunci: magis, politik lokal, pemilihan kepala desa, Banten

\section{Pendahuluan}

Pemilihan kepala desa (pilkades) dianggap sebagai arena demokrasi yang paling nyata di desa. Dalam pilkades terjadi kompetisi yang bebas, partisipasi masyarakat, pemilihan secara langsung dengan prinsip one man one vote. Namun di banyak desa, proses pemilihan kepala desa yang berlangsung secara demokratis seringkali terjadi kecurangan-kecurangan dan dengan cara yang tidak sehat, bahkan sebagian calon kepala desa menggunakan cara-cara supernatural untuk 
memenangkan pemilihan. Sebagian ada yang mempercayai dukun-dukun untuk memperlancar pemenangan mereka atas PILKADES, sebagian yang lain lebih suka mengunjungi kiai-kiai atau ahli hikmah untuk meminta doa restu sekaligus meminta amalan-amalan, wafak, jimat dan yang sejenisnya dengan tujuan yang sama.

Kepercayaan masyarakat terhadap kekuatan-kekuatan supernatural dan praktik-praktik magic sudah ada sejak zaman dahulu kala. Dalam hal ini, O'Keefe berpendapat bahwa magic tidak hanya ditemukan pada zaman batu dan pada masyarakat primitif saja, tapi juga bisa ditemui di hampir setiap masa, disetiap masyarakat dimanapun dan magic muncul di banyak kebudayaan di dunia (O'Keefe 1982). Ini berarti bahwa magic adalah sebuah fenomena sosial yang real yang ada baik pada masyarakat primitif maupun masyarakat modern. Karenanya hampir setiap orang percaya bahwa magic itu betul-betul ada dan terjadi dalam area kehidupan mereka dan mereka percaya bahwa situasi-situasi sosial bisa dipengaruhi, diubah, disembuhkan, dihancurkan dan ditransformasikan dengan tindakan-tindakan magis. Dalam hal ini, Malinowski berargumen bahwa magic bisa membangun kepercayaan dalam situasi-situasi yang tidak pasti (Malinowski 1954).

Pendapat Malinowski di atas barangkali bisa dijadikan sandaran mengapa dalam proses pemilihan kepala desa yang bersifat demokratis masih ada kepercayaan-kepercayaan dan praktik-praktik magis untuk mencapai tujuan yang diharapkan. Hal ini tentu saja tidak bisa dilepaskan dari kepercayaan masyarakat yang masih tinggi atas kekuatan gaib yang dianggap mampu membantu mewujudkan harapan dan keinginan mereka atas kondisi yang tidak menentu tersebut. Selanjutnya Malinowski berpendapat bahwa sebagaimana agama, magic juga muncul dan berfungsi dalam situasi-situasi emotional stress seperti dalam kondisi krisis, dalam kondisi kosong atau hampa karena mengejar sesuatu yang dianggap penting, kehidupan cinta yang tidak bahagia dan kebencian (Malinowski 1954). Pemenangan atas pemilihan kepala desa dalam hal ini dianggap sebagai sesuatu yang penting bagi para calon karena selain dapat menaikkan status sosial mereka dimasyarakat, mereka juga dapat memperoleh keuntungan secara ekonomi. Karenanya, menjadi penting bagi sebagian calon untuk memperoleh dukungan dari masyarakat dengan berbagai cara, baik yang rasional maupun yang irasional.

Sebagaimana diketahui, masyarakat Banten bukan hanya terkenal dengan masyarakatnya yang relijius yang menurut laporan - laporan kolonial Belanda mereka dianggap sebagai muslim yang paling fanatik kedua di Nusantara-setelah Aceh- dan dikenal lebih taat dalam menjalankan perintahperintah agama, tapi juga, menurut Martin van Bruinessen, memiliki reputasi yang kuat sebagai ' $a$ heaven of occult sciences' (Bruinessen 1995). Oleh karena itu, tidak mengherankan apabila dalam proses pemilihan kepala desa, banyak dari calon kepala desa di Banten, khususnya di Kecamatan Padarincang, masih menggantungkan harapan mereka pada kekuatan-kekuatan supernatural. Mereka percaya bahwa dengan meminta bantuan para magician (seperti ahli hikmah dan dukun), para calon akan lebih percaya diri mampu memenangkan pemilihan kepala desa.

Berdasarkan penjelasan di atas, berbicara tentang penggunaan magic dalam politik lokal di Banten menjadi subjek yang menarik untuk dikaji karena beberapa alasan. Pertama, Proses pemilihan kepala desa yang selayaknya dilakukan dengan cara-cara yang fair, bersih dan berdasarkan sistem LUBER, ternyata masih menjadi ajang kompetisi yang tidak sehat dengan menggunakan kekuatankekuatan supernatural yang dianggap mampu membantu para calon untuk memenangkan pemilihan. Kedua, masyarakat Banten yang dikenal dengan kefanatikan dan ketaatannya dalam menjalankan ritual-ritual keagamaan, ternyata masih memiliki pengikut yang loyal yang percaya akan kekuatan-kekuatan magic yang mampu mengubah dan membantu mewujudkan impian-impian mereka. Ketiga, penggunaan magic dalam proses pemilihan kepala desa adalah sebagai sebuah fenomena sosial yang real di Banten yang belum pernah dikaji oleh peneliti manapun.

Artikel ini mencoba menjawab beberapa pertanyaan sebagai berikut: Mengapa calon kepala desa memanfaatkan magis dalam proses pemilihan? Jenis magic apa saja yang digunakan oleh para calon kepala desa dalam proses pemilihan kepala desa? Bagaimana proses pemanfaatan magic dalam proses pemilihan kepala desa? 


\section{Metode Penelitian}

Penelitian ini menggunakan metode etnografi yang bersifat deskriptif kualitatif dengan menggunakan pendekatan antropologis. Dalam menganalisis data, peneliti menggunakan pendekatan fungsional-struktural (structural-functional approach). Metode yang digunakan untuk mengumpulkan data adalah kajian pustaka, observasi, dan wawancara mendalam. Wawancara dilakukan kepada informan terutama para calon kepala desa, mantan kepala desa, kepala desa incumbent, kiai, ahli hikmah, dukun, tokoh masyarakat, dan masyarakat Banten khususnya yang tinggal di Kecamatan Ciomas dan Kecamatan Padarincang.

\section{Hasil dan Pembahasan}

\section{Kepercayaan masyarakat Banten terhadap magic}

Manusia modern cenderung sering mengasosiasikan magic dengan masyarakat primitif, masyarakat suku tradisional, masyarakat pra-industri dan pra-modern. Masyarakat modern biasanya dipandang sebagai masyarakat di mana rasionalitas ilmiah, modern dan paham teknologi berlaku secara menyeluruh sehingga tidak ada tempat bagi pemikiran dan perilaku magis. Akan tetapi, meskipun di satu sisi masyarakat modern mencoba mengesampingkan dimensi magis dalam kehidupan mereka dan mereka sering mengasosiasikan perilaku magis dengan masyarakat primitif dan tradisional, sebenarnya mereka tidaklah betul-betul menghilangkan dan membuang dimensi magis dalam kehidupan mereka. Satu contoh mereka masih percaya dengan Horoskop, zodiak, terapiterapi dan pengobatan alternatif dan sebagainya. Ini membuktikan bahwa dimensi magic tidak pernah terhapus dari masyarakat modern.

Para ahli antropologi seringkali mengingatkan dan menunjukan bahwa ada banyak kepercayaan dan praktik magic pada masyarakat beradab dan modern (modern and civilized society) yang pada dasarnya tidak berbeda dengan kepercayaan dan praktik magic yang ada pada masyarakat tradisional dan primitif. Menurut Hamilton, kalaupun ada perbedaan antara masyarakat modern dan masyarakat primitif berkaitan dengan kepercayaan dan praktik magic adalah lebih bersifat kuantitas ketimbang kualitas (Hamilton 2002). Ini artinya bahwa masyarakat primitif mungkin secara kuantitas lebih banyak menggantungkan dan memecahkan masalah yang mereka hadapi kepada kepercayaan dan kekuatan magic, sedangkan bagi masyarakat modern dimana teknologi dan beragam perlengkapan modern yang dibutuhkan oleh manusia sudah banyak tersedia, mereka cenderung lebih banyak menggantungkan dan memecahkan masalah hidup mereka dengan caracara modern yang dianggap lebih rasional. Akan tetapi, sebagaimana yang dinyatakan oleh Hamilton di atas, bahwa secara kualitas esensi dari magic yang dipraktikan oleh dua masyarakat yang berbeda ini sebenarnya sama, yaitu bahwa mereka percaya bahwa ada kekuatan luar biasa diluar dirinya yang bisa mengontrol, mengubah, menghancurkan dan mentransform dirinya dan alam disekitarnya. Oleh karena itu, meskipun lebih kecil tingkat kepercayaan dan kecenderungan mereka terhadap kekuatan magic, sebenarnya mereka masih percaya, bahkan menggunakannya dalam kehidupan mereka.

Apa yang dinyatakan oleh para antropolog di atas barangkali bisa dijadikan pedoman bagi praktik magic pada masyarakat Banten. Masyarakat Banten, meskipun memilki suatu wilayah yang dianggap masih primitif dan tradisional, yaitu masyarakat Baduy, akan tetapi sebagian besar masyarakatnya adalah masyarakat yang berpendidikan, beradab dan modern. Beragam alat dan perlengkapan teknologi modern sudah bisa digunakan dan diakses oleh masyarakat sampai ke pedesaan. Akan tetapi, meskipun peralatan modern dan akses informasi dan teknologi modern sudah dikenal dan digunakan oleh masyarakat Banten dalam kehidupan keseharian mereka, kepercayaan masyarakat terhadap kekuatan dan praktik magic masih bertahan di Banten. Bahkan, bagi masyarakat luar, Banten dianggap sebagai pusatnya praktik magic. Banyak orang yang mau mempelajari atau mau meminta khasiat akan kekuatan magic datang ke Banten. Ini menunjukan bahwa Banten sebagai the central spot of magical practices menjadi identitas budaya masyarakat Banten dalam pandangan orang luar. 
Kepercayaan dan keyakinan sebagian masyarakat Banten terhadap magic nampaknya bukan hanya karena secara naluriah mereka memiliki kecenderungan terhadap hal-hal yang bersifat mistis dan magi, tapi juga oleh karena pengaruh sosial budaya masyarakat Banten sendiri di mana praktikpraktik magic mendapat legitimasi dari tokoh-tokoh agama (kiai dan ahli hikmah) yang dipandang sebagai figur-figur yang memiliki otoritas untuk menafsirkan agama. Oleh karena sumber-sumber magic yang dijadikan referensi oleh tokoh-tokoh tersebut diyakini berasal dari teks-teks suci (alQur'an dan hadits). Sebagian masyarakat Banten merasa yakin bahwa Islam tidak hanya menawarkan petunjuk untuk keselamatan dunia dan akhirat, tetapi juga menawarkan solusi praktis bagi berbagai permasalahan hidup manusia melalui jalan magi. Nampaknya faktor-faktor inilah yang menjadi salah satu sebab mengapa hingga saat ini budaya dan tradisi magic di Banten masih sangat kuat, walaupun ada sebagian kiai dan sekelompok masyarakat Muslim Banten yang lain yang menolak, bahkan mengharamkan praktik-praktik magic.

Magi, sebagaimana didefinisikan oleh Mauss sebagai bentuk paling awal dari pemikiran manusia dan menjadi fondasi dasar dari seluruh bidang keilmuan dan mistis manusia primitif (Mauss 1972) sebenarnya masih dipraktikkan oleh sebagian masyarakat modern, tidak terkecuali masyarakat Muslim Banten. Di Banten, tidak hanya masyarakat pedesaan dan masyarakat yang tidak mengenal pendidikan tinggi yang meyakini dan mempraktikkan ilmu-ilmu magic, masyarakat perkotaan dan yang sudah berpendidikan tinggi sekalipun masih mempercayai dan memanfaatkan kemampuankemampuan magic para ahli magic untuk berbagai tujuan hidup mereka. Nampaknya magic menjadi salah satu identitas religio-kultural masyarakat Banten.

Penjelasan di atas kelihatannya menegaskan pandangan O'Keefe bahwa magic tidak hanya ditemukan pada zaman batu dan pada masyarakat pre-literate saja, tapi juga dapat ditemui di hampir setiap masa, di setiap masyarakat di manapun dan magic muncul di banyak kebudayaan di dunia (O'Keefe 1982). Hal ini berarti bahwa magic adalah sebuah fenomena sosial real yang ada baik pada masyarakat pre-literate maupun masyarakat modern. Karena hampir setiap orang percaya bahwa magic itu betul-betul ada dan terjadi dalam area kehidupan mereka dan mereka percaya bahwa situasi-situasi sosial dapat dipengaruhi, diubah, disembuhkan, dihancurkan dan ditransformasikan dengan tindakan-tindakan magi.

Dalam kehidupan sosial, praktik magic seringkali menjadi bagian penting dalam interaksi kehidupan sosial masyarakat Banten. Interaksi yang bersifat sibernetik atau simbiosis mutualisme terjadi antara si pemilik magic dengan masyarakat. Seorang kiai yang terkenal dapat mengobati penyakit baik medis maupun non-medis, dapat memberikan doa, wiridan, wafak, jimat dan sejenisnya untuk kepentingan bisnis dan usaha, dapat menjadikan sepasang lawan jenis saling mencintai atau sebaliknya, dapat mengembalikan barang, benda atau orang hilang, dan memiliki berbagai kemampuan supernatural lainnya. Para kiai yang memiliki kekuatan akan memiliki banyak pengikut, baik pengikut yang menjadi santri maupun yang hanya datang untuk mengatasi persoalan hidup dan kebutuhan praktis lainnya.

Silaturahmi dan ikatan antara kiai dan pengikutnya seringkali bukan hanya dalam jangka waktu pendek atau sesaat, tapi seringkali berlaku dalam jangka waktu yang tidak terbatas, bahkan ketika si kiai sudah meninggal dunia, ikatan emosional antara si kiai dan pengikutnya terus berlangsung. Indikasi keberlangsungan ikatan emosional ini dapat kita lihat pada fakta bahwa banyak pengikut maupun orang-orang yang berharap berkah dari kesucian dan karomah sang kiai datang untuk berziarah ke makam sang kiai, bahkan ketika sang kiai sudah meninggal puluhan atau bahkan ratusan tahun yang lalu. Dalam hal ini, K.H. Fy (personal communication 2009), seorang ahli hikmah asal Ciomas menuturkan:

"Saya belajar ngahikmah ke banyak guru (kiai), baik yang berasal dari Banten maupun dari luar Banten. Minimal setahun sekali, saya selalu menyempatkan diri datang bersilaturahmi ke guru saya. Kalau misalnya guru saya sudah meninggal dunia, silaturahmi tetap saya lakukan ke keluarga guru saya, dan juga berziarah ke makam guru saya tersebut. Bahkan, setiap malam atau setiap saya melakukan wiridan, saya selalu menghadiahkan al-fatihah ke 
guru-guru saya. Ini saya lakukan agar ilmu yang saya terima dari guru-guru saya barokah dan manfaat. Seorang murid tidak boleh seperti kacang lupa kulitnya, setelah memperoleh ilmu dari gurunya, gurunya dilupakan begitu saja, nanti ilmunya tidak barokah dan kurang manfaat. Minimal, kita mengirimkan hadiah al-fatihah atau salawat setiap ba'da shalat maghrib. Dan saya yakin, semua kiai atau ahli hikmah akan melakukan hal yang sama, selalu mendoakan dan bersilaturahmi dengan guru. Ini sebagai tanda khidmat dan penghormatan kita kepada guru".

Hal yang sama juga diakui oleh beberapa ahli hikmah yang lain. Mereka masih membiasakan untuk bersilaturahmi dan terus berkomunikasi dengan guru-guru mereka. Bahkan, sebagian ahli hikmah merutinkan untuk mendatangi guru mereka, selain untuk bersilaturhami, juga untuk menambah ilmu dan wawasan mereka baik dalam bidang agama maupun dalam hal ilmu hikmah.

\section{Mengapa calon kepala desa menggunakan magic?}

Di Banten, beragam praktik magic bisa ditemukan, dari white magic sampai black magic. Banyak ahli magic bisa mengajarkan dan dimintai berbagai jenis ilmu magic, seperti kiai, ahli hikmah dan dukun (Tihami 1992). Ketiga kelompok masyarakat Banten ini seringkali didatangi oleh orangorang, baik dari dalam maupun dari luar Banten untuk dimintai doa, sekaligus juga diminta beragam ilmu supernatural mereka. Keahlian tiga figure ini dalam memecahkan masalah praktis yang dihadapi masyarakat Banten tidak diragukan lagi menjadi magnet bagi para pencari kekuasaan, posisi dan jabatan untuk memenuhi tujuan dan keinginan mereka. Salah satunya adalah para calon kepala desa yang menginginkan dirinya menjadi pemenang dalam proses pemilihan kepala desa.

Meskipun sebagian besar dari para calon kepala desa di Kecamatan Ciomas dan Kecamatan Padarincang adalah orang-orang yang berpendidikan (salah satu kepala desa bahkan lulusan Sarjana Teknik di salah satu univeritas negeri di Banten (Hananudin 2009), tetapi mereka masih mempercayai kekuatan magic bisa membantu mereka memenangkan Pilkades. Kepercayaan sebagian besar masyarakat Banten akan kekuatan magic dan kemampuan beberapa ahli magic di Banten untuk menggunakan kekuatan supernatural mereka, membuat mereka yakin dan percaya diri bahwa dengan meminta doa dan juga menggunakan benda-benda atau ritual ritual magis yang diberikan oleh ahli-ahli magic tersebut, mereka bisa menang dalam Pilkades.

Setiap calon kepala desa yang mendatangi ahli-ahli magic itu tentu didasari karena keinginan memenangkan Pilkades. Tentu ada alasan mendasar yang menyebabkan mereka memanfaatkan magic untuk proses pencalonan kepala desa. Berdasarkan informasi yang berhasil peneliti himpun dari beberapa informan di dua kecamatan ini, peneliti mencoba menggarisbawahi beberapa poin yang menjadi alasan mendasar kenapa para calon kepala desa ini memanfaatkan magic untuk memenangkan Pilkades, yaitu: 1) Sebagai bentuk realisasi dari nyari'at (ikhtiar atau usaha) yang bersifat batiniah; 2) mereka memiliki rasa kurang atau tidak percaya diri dengan kemampuan mereka sendiri dalam memenangkan Pilkades; 3) sebagai bentuk counter-magic karena meyakini bahwa calon yang lain juga melakukan hal yang sama; 4) karena dorongan dari keluarga, tetangga atau pendukung; 5) ada keyakinan bahwa dengan menggunakan magic, masyarakat akan terpengaruh dan merasa lebih welas asih kepada calon dan suara tidak terpecah ke calon yang lain; 6) mereka meyakini bahwa kekuatan magic dapat memunculkan kharisma sebagai pemimpin, sehingga masyarakat segan dan memilihnya menjadi pemimpin desa; 7) sudah menjadi kebiasaan atau tradisi yang umum bagi masyarakat Banten bahwa para calon kepala desa atau bahkan caleg, calon bupati dan sebagainya yang memiliki keinginan untuk memenangkan pemilihan mendatangi para ahli magi. Fenomena seperti ini lazim dan umum ditemui di berbagai wilayah di Banten. 


\section{Jenis dan ragam magic yang digunakan dalam proses Pilkades}

Dalam proses Pilkades, ada banyak ragam magic yang digunakan untuk membantu calon kepala desa memenangkan Pilkades. Jenis dan ragam magic ini sama-sama diyakini oleh ahli magic dan si calon kepala desa, bisa membuat suara mereka unggul pada saat pemilihan.

Pada bagian ini, peneliti mencoba menguraikan alat dan media apa saja yang digunakan oleh ahliahli magic baik kiai hikmah maupun dukun untuk membantu calon kepala desa memenangkan Pilkades. Selanjutnya darimana sumber magic yang digunakan oleh para ahli magic itu berasal, selanjutnya bentuk dan jenis magic juga jadi salah satu hasil dari penelitian ini diikuti dengan uraian tentang manfaat dan tujuan jenis magic tersebut, terakhir peneliti akan mencoba mengupas pendapat para ahli magic tentang seberapa besar pengaruh magic terhadap pemenangan Pilkades.

\section{Alat dan media magic untuk proses Pilkades}

Mauss, seorang antropolog yang menulis tentang The General Theory of Magic dalam bukunya menjelaskan bahwa ada tiga elemen penting dalam magic. Yang pertama adalah magician (ahli magic). Dalam hal ini, kiai, ahli hikmah dan dukun pada masyarakat Banten masuk dalam kategori magician, karena mereka adalah orang-orang yang dianggap memiliki dan mempraktikan ilmu gaib (magic). Elemen yang kedua adalah actions atau tindakan (aktivitas magic). Dalam hal ini, Mauss mendefinisikan action sebagai ritual. Dia menyatakan "The actions of a magician are rites"'(Mauss1972: 55). Elemen penting ketiga dari magic adalah representation (Mauss 1972: 55). Elemen kedua dan ketiga yang dimaksud oleh Mauss inilah yang mengandung unsur alat dan media yang digunakan oleh para ahli magic di Banten. Satu contoh adalah mantra, wafak dan amalan yang menjadi salah satu alat dan media dalam praktik magic di Banten. Verbal rites sejenis mantra adalah salah satu bentuk actions yang dimaksud oleh Mauss diatas dan representasinya bisa dalam bentuk tulisan wafak maupun benda-benda magic tertentu yang dianggap mempunyai khasiat untuk tujuan yang diinginkan. Mantra atau formula magic, menurut Malinowski merupakan pusat atau inti dari magical performance (Malinowski 1954).

Berdasarkan informasi yang peneliti peroleh dari kiai, ahli hikmah, dukun, dan beberapa kepala desa, mantan kepala desa, dan mantan calon kepala desa di Kecamatan Ciomas dan Kecamatan Padarincang, ada beberapa alat dan media yang sering digunakan oleh calon dalam proses Pilkada yang diyakini berkhasiat membantu mereka memenangkan Pilkades.

Air

Air dianggap sebagai alat dan media yang paling sering digunakan baik oleh dukun maupun kiai hikmah untuk membantu calon Kepala desa. Air yang sudah diisi dengan amalan atau wiridan tertentu oleh ahli magic bisa digunakan untuk berbagai tujuan. Air dianggap punya pengaruh magic yang cukup besar, karena mereka memandang air adalah sumber kehidupan. Tanpa air manusia atau makhluk hidup lainnya tidak akan bisa hidup. Disamping mudah di dapat, air juga diyakini memiliki khasiat magic yang bersifat alamiah, apalagi kalau sudah ditulisi wafak, dibacakan mantra-mantra tertentu, tentu khasiatnya akan lebih besar. Bahkan salah satu dukun yang menggunakan air laut sebagai media magic, mengatakan bahwa air yang dia peroleh dan dia berikan kepada calon kepala desa, bukan sembarang air. Air itu dia dapatkan langsung dari Nyi Roro Kidul, Penunggu atau Ratu Pantai Selatan, yang dianggap sebagai pemimpin mahluk gaib di Banten, dengan cara melakukan tirakat dan ritual tertentu di Pelabuhan Ratu (Bsn 2009). Peneliti saat melakukan wawancara, diizinkan untuk melihat, mengamati dan mendokumentasikan air yang digunakan oleh dukun tersebut. Air tersebut dimasukan dalam botol Aqua besar. Air tersebut berwarna agak keruh dan bercampur dengan sejenis akar-akaran, dan juga satu lembar kecil tulisan berbahasa Arab. Dukun tersebut mengatakan bahwa yang ada di botol tersebut semuanya sudah dari sananya (dari Nyi Roro Kidul), dia sendiri tidak tahu akar apa yang ada dalam air tersebut. Tulisan arab yang tertulis dalam lembaran tersebut ternyata diambil dari ayat Al-Qur'an, yaitu surat YaaSiin, ayat 15 , dikatakan punya khasiat banyak, salah satunya untuk memenangkan Pilkades. Air itu 
nantinya disiramkan di empat sudut desa dimana si calon akan mencalonkan diri jadi Kepala desa. Air ini diyakini bisa membuat warga yang tinggal di situ akan welas asih kepada si calon dan hatinya akan selalu ingat kepada si calon ketika hari-H. Karena desa itu sudah dikurung oleh air sakral tadi.

Selain itu, air suci yang sudah di isi tersebut bisa juga dicampur dengan minuman atau makanan, atau dimasukkan ke sumur-sumur penduduk atau ke sungai dimana masyarakat biasa mengambil air tersebut untuk minum. Dengan begitu, warga yang meminum air yang sudah dicampur dengan air suci itu diyakini akan selalu ingat dan welas asih kepada si calon. Penggunaan air seperti ini biasanya diberikan oleh ahli hikmah.

\section{Tanah}

Selain air, tanah juga dianggap sebagai media penting yang bisa digunakan untuk keperluan magic. Tanah dianggap memiliki kekuatan magic secara alamiah, karena manusia tercipta dari tanah dan akan kembali menjadi tanah. Inilah yang membuat salah satu dukun di Banten menggunakan tanah sebagai media yang bersifat magic untuk membantu calon kepala desa. Empat gumpal tanah yang diambil dari empat sudut desa dan juga sudah diisi (diwiridi atau dibacakan mantra-mantra magic tertentu), dibungkus dengan kain putih, kemudian dipendam di lapangan yang akan digunakan untuk tempat TPS. Empat gumpal tanah tersebut, dipendam di empat sudut lapangan. Dukun yakin, bahwa lapangan yang sudah dilingkari dengan tanah berisi magic tersebut akan diselubungi oleh kekuatan magic, karena dia juga sudah menyuruh 4 jin yang dimasukan bersama tanah itu kedalam kain putih untuk menunggu lapangan yang akan dijadikan TPS, sampai perhitungan suara selesai. Dukun yakin bahwa orang yang masuk kedalam lapangan tersebut nantinya hanya akan melihat si calon yang menggunakan magic dari tanah ini, sedangkan calon atau gambar calon yang lain tampak samarata bahkan tidak terlihat sama sekali. Dengan begitu, otomatis orang akan mencoblos calon yang gambarnya kelihatan oleh mereka (Dyt 2009).

\section{Rokok}

Rokok, ternyata bisa dijadikan media yang efektif untuk diisi dengan kekuatan magic oleh ahli magic di Banten. Harganya yang murah, mudah didapat dan tentunya keberadaannya yang sudah diisi mahluk gaib tidak akan dicurigai oleh orang lain, karena kebiasaan mereka sudah menjadi kebiasaan umum di masyarakat kita. Oleh karena itu, dukun dan beberapa ahli hikmah kadang menggunakan rokok sebagai alat atau media yang bisa diisi dengan kekuatan magic untuk membantu pemenangan Pilkades. Rokok yang sudah diwiridi dan dirituali oleh ahli magic, bisa digunakan sebelum hari $\mathrm{H}$ dan juga pas pelaksanaan pemilihan. Biasanya dukun pada hari $\mathrm{H}$, akan berkeliling diseputar lapangan TPS sambil merokok. Mau tidak mau, asap yang sudah berisi magic tersebut akan terhisap dan tercium oleh warga yang ada didekatnya. Dengan begitu, si dukun meyakini bahwa warga yang sudah menghisap asap rokok yang sudah diisi dengan benda magis tersebut, akan berpengaruh kepada kecendrungan seseorang yang mau masuk ke bilik TPS. Si warga kemungkinan hanya akan melihat gambar si calon yang dibantu oleh dukun tersebut, atau bisa juga hatinya selalu ingat dan terbayang-bayang wajah si calon. Dengan begitu, si dukun yakin bahwa warga tersebut pada akhirnya akan mencoblos gambar si calon yang dimaksud (Slmt 2009).

\section{Jenis dan bentuk magic untuk Pilkades}

\section{Susuk}

Susuk adalah jenis magic yang paling umum dan paling sering digunakan oleh ahli magic di Banten, baik dukun maupun ahli hikmah. Susuk adalah benda magic yang disisipkan kedalam kulit atau anggota badan seseorang, atau kadang ditelan, yang diyakini memiliki beragam manfaat magis. Alat atau media yang digunakan oleh ahli hikmah maupun dukun untuk susuk beragam, ada yang berbentuk butiran berlian, intan, emas, perak, besi, timah, bulu macan dan lain sebagainya. Masing-masing jenis susuk ini punya manfaat dan khasiat magis yang berbeda. Berlian, intan, emas 
dan perak biasanya digunakan apabila seseorang ingin terlihat lebih cantik, lebih ganteng, dan disukai dan dicintai oleh banyak orang. Bisa juga digunakan untuk menimbulkan kharisma, sehingga orang lain yang melihatnya akan segan dan hormat kepada si pemakai, bisa juga agar apapun yang diucapkan oleh si pemakai, dipercaya dan dianggap benar oleh orang lain. Sementara susuk dari bulu macan biasanya berkhasiat untuk wibawa atau penyeram (untuk membuat seseorang tanpa seram dan ditakuti oleh orang lain). Susuk jenis ini juga bisa digunakan untuk keselamatan.

Calon Kepala Desa yang ingin dirinya nampak kelihatan lebih gagah, lebih berwibawa, lebih disegani dan dihormati oleh warga, sangat dianjurkan untuk menggunakan susuk ini. Adapun jenis susuk yang digunakan oleh calon kepala desa tergantung pada tujuan dan maksud yang diinginkan oleh si calon. Dan biasanya ini penggunaan susuk juga tergantung mahar (bayaran) yang bisa diberikan oleh sipemakai kepada ahli magic. Semakin mahal mahar yang harus dibayar, semakin baik atau bagus khasiat magic yang akan diperoleh.

\section{Wafak}

Wafak biasanya berupa tulisan berbahasa Arab, Jawa Pegon atau bahasa Jawa lama yang ditulis disehelai kertas, kain atau kulit binatang tertentu yang diyakini memiliki khasiat magis. Ahli hikmah biasanya mengambil sumber untuk wafak dari kitab-kitab Arab klasik tertentu yang sudah umum dipakai untuk keperluan membuat wafak. Untuk menulis sebuah wafak, seorang ahli hikmah tidak begitu saja mengambil dan menjiplaknya dari kitab wafak tersebut. Mereka harus menghitung dulu nama si calon, hari lahir, bulan lahir (bulan Hijriah), hari ketika si calon meminta wafak tersebut, dan nama orang tua. Semua nama-nama ini ditulis dalam bahasa Arab. Kemudian tiap huruf dikonversikan kedalam angka dimana konversi dari huruf Arab ke angka ini bisa dilihat dalam salah satu kitab hikmah, setelah dikonversikan kemudian angka-angka itu dijumlahkan dan dikurangkan dengan hitungan yang cukup rumit. Setelah dihitung dengan perhitungan yang rumit tadi, sisa angka kemudian dicocokkan kedalam tabel lauhil hayat dan tabel lauhil mamat yang ada disalah satu kitab hikmat. Kalau kebetulan sisa angka masuk dalam tabel lauhil hayat, berarti wafak bisa ditulis malam itu juga dan diyakini akan berkhasiat bagi sipemakainya. Kalau angka sisa masuk dalam tabel lauhil mamat, artinya hari itu kurang bagus atau tidak tepat untuk menulis wafak buat si calon. Si calon harus datang lagi dihari yang lain, atau bisa juga dengan menggunakan nama kecilnya, sehingga angka sisa betul-betul cocok dengan tabel dalam kolom lauhil hayat. Lauhil hayat artinya hari bagus atau hari beruntung bagi orang tersebut, sedangkan lauhil mamat artinya hari itu kurang bagus atau tidak membawa keberuntungan bagi si calon (Munawir 2009).

Bahkan untuk memulai aktivitas, jam berapa si calon harus keluar rumah ketika hari $\mathrm{H}$, dan hal-hal detil lainnya dibahas dalam kitab-kitab hikmat ini secara detil, setelah penentuan hari bagus dan hari naas untuk pembuatan wafak itu didapat.

Sebagaimana yang dilakukan ahli hikmah, dukun pun ketika akan membuat wafak tidak sembarangan. Dia juga harus melakukan petungan untuk menentukan hari bagus dan hari naas bagi si calon. Yang berbeda barangkali hanyalah sumber yang digunakan untuk menghitung hari bagus tersebut. Kalau ahli hikmat mengambilnya dari kitab-kitab hikmat, sedangkan dukun mengambilnya dari lembaran-lembaran tertentu (ada yang berbahasa Arab dan ada juga yang berbahasa Jawa) yang ditulis tangan. Untuk menentukan hari bagus dan hari naas untuk membuat wafak ini, sama rumitnya dengan yang dilakukan oleh ahli hikmat.

Dari penjelasan diatas, jelas bahwa baik ahli hikmah maupun dukun keduanya menggunakan wafak sebagai salah satu bentuk dan jenis magic yang memiliki khasiat beragam, ada wafak untuk keselamatan, keberanian, wibawa, karisma, welas asih dan sebagainya. Biasanya dalam satu wafak, bisa untuk beberapa khasiat. Dengan memakai wafak ini, si calon yakin dirinya akan selamat dan sukses dalam Pilkades. 
Jimat

Jimat dalam Kamus Besar Bahasa Indonesia diartikan sebagai benda yang dianggap mengandung kesaktian contohnya dapat menolak penyakit, menyebabkan kebal dan sebagainya (Ali 1998:415). Istilah lain yaitu azimat juga kurang lebih didefinisikan sama dengan pengertian zimat pada kamus ini, yaitu "barang (tulisan) yang dianggap mempunyai kesaktian dan dapat melindungi pemilinya, digunakan sebagai penangkal penyakit dan sebagainya" (Ali 1998:415). Dari pengertian tersebut diatas, jelas bahwa jimat adalah benda-benda magis yang digunakan untuk mencapai tujuan dan keinginan yang diinginkan dengan kekuatan magis yang dimiliki oleh benda tersebut.

Benda-benda magic jenis ini sangat beragam, ada yang berbentuk cincin, keris kecil, batu hitam, batu merah delima, mani gajah berbentuk seperti mutiara, wayang yang bertuliskan huruf Arab, dan lain sebagainya. Benda-benda magis ini biasanya diakui didapatkan dengan cara melakukan ritual atau tirakat tertentu ditempat-tempat yang dianggap sakral. Ada juga yang didapat oleh si pemilik azimat melalui mimpi, biasanya ketika bangun orang tersebut mendapatkan jimat tersebut ada disampingnya atau ada ditempat yang ditunjukan dalam mimpi tersebut. Bapak Bsn mengakui sebagian jimat yang dimiliki diperoleh dengan cara melakukan ritual di tempat-tempat sakral tertentu, ada juga yang diperolehnya dari Nyi roro Kidul yang dianggapnya sebagai guru magicnya.

\section{Amalan atau wiridan}

Amalan atau wiridan adalah bacaan-bacaan tertentu yang diambil dari ayat Al-Qur'an atau, hadits Nabi yang dibaca berualang-ulang selama jangka waktu tertentu. Amalan atau wiridan ini ada yang berupa amalan atau wiridan biasa sehari-hari, ada juga amalan yang khusus digunakan untuk maksud tertentu. Bacaan amalan atau wiridan ini diyakini punya nilai magic bagi penggunanya. Oleh karena itu, biasanya kiai atau ahli hikmah memberikan bacaan-bacaan tertentu yang diambil dari Al-Qur'an atau dari kitab-kitab hikmah kepada si calon agar diamalkan pada waktu waktu tertentu. Jumlah yang harus dibaca juga beragam, tergantung jenis wiridannya.

Apapun bentuk wiridan atau bacaan yang dibaca dan diamalkan oleh para calon atau oleh ahli magic sendiri tentunya diyakini memiliki nilai magis, yang jika diamalkan secara regular dan sesuai dengan aturan, waktu dan cara-cara tertentu, tentu akan membawa manfaat, khasiat dan pengaruh yang besar bagi kemenangan si calon dalam proses Pilkades. Ini artinya bahwa, wiridan dan amalan merupakan satu bentuk atau jenis magic tertentu yang diyakini oleh masyarakat Banten, untuk mencapai tujuan-tujuan yang diinginkan dengan bantuan dari bacaan-bacaan yang dianggap mengandung nilai magis tertentu.

\section{Mantra}

Kalau kiai hikmah (ahli hikmah) lebih banyak menggunakan wiridan atau bacaan- bacaan tertentu yang diambil dari Al-Qur'an, kitab-kitab hikmat atau dari bacaan Asmaul-Husna yang dianggap memiliki nilai magis sebagai bacaan untuk diamalkan (diwirid) oleh si calon selama proses Pilkades sampai hari pencoblosan, dukun biasanya menggunakan mantra berbahasa jawa, walaupun diantara mereka juga ada yang memberikan jenis wiridan atau amalan sebagaimana yang diberikan oleh ahli hikmah. Disinilah yang kadang kala membingungkan peneliti untuk membedakan antara ahli hikmah dan dukun di Banten, karena kadang-kadang jenis dan sumber magic yang digunakan sama.

Mantra menurut Malinowski adalah bagian paling penting dari praktik magic. Mantra adalah bagian magic yang bersifat gaib (magis), yang diberikan dalam aktivitas magic dan hanya diketahui oleh praktisi atau ahli magic. Bagi para penduduk asli yang diteliti oleh Malinowski, ilmu magic berarti juga ilmu mantra, artinya bahwa orang yang ahli atau mengetahui mantra dianggap sebagai dukun atau orang yang punya ilmu magic. Dari hasil analisisnya pada berbagai aksi tenung (witchcraft), akan selalu ditemukan bahwa pusat ritual berpusat pada mantra-mantra yang diucapkan. 
Menurutnya, formula magic (mantra) selalu menjadi 'the core of the magical performance' (Malinowski 1954).

Begitu juga di Banten, dalam setiap aktivitas magic pasti ada bacaan-bacaan tertentu, baik itu berbentuk mantra maupun wiridan yang dibaca oleh ahli magic yang kadangkala maknanya tidak dipahami oleh orang biasa, baik untuk mengobati penyakit maupun mengusir roh jahat ada mantramantra tertentu yang dibacakan oleh dukun yang diyakini mampu berpengaruh terhadap kondisi si pasien sesuai dengan tujuan yang diinginkan. Dalam proses pemilihan kepala desa, ada beberapa jenis mantra yang juga diberikan oleh dukun agar dibaca oleh si calon pada waktu, tempat dan caracara tertentu, selain mantra yang dibaca oleh si dukun itu sendiri mulai malam sebelum pencoblosan sampai hasil penghitungan suara selesai diumumkan. Di antara mantra yang diberikan dukun kepada calon Kepala Desa adalah:

\section{Bismillaahir Rahmaanir Rahiim}

Semar wijaya kang kinasihan putra abdi pangirutan, sangadoh sangarubung, gede cilik tua enom lanang wadon kudu inget maring badan isun kabeh, ditilik ti gigir lenggik, diteuteup ti harep sieup, disawang ti tukang leunjang, mangka welas mangka asih atine si....(wong kabeh).” (Bsn 2009)

Mantra tersebut di atas, menurut Bpk. Bsn, berkhasiat agar seseorang atau masyarakat banyak welas asih dan selalu ingat kepada si calon, sehingga pada saat pencoblosan si calon bisa dipilih. Selain bacaan tersebut di atas, ada bacaan-bacaan lain yang juga dibaca (diamalkan) baik oleh si calon maupun oleh si dukun itu sendiri. Adapun menurut Bpk. Dayat, biasanya mantra dia amalkan sendiri, sementara si calon hanya diberi wiridan dari al-Qur'an. Menurutnya, mantra yang dia gunakan berasal dari kitab Jawa Kuno yang sudah berumur ratusan tahun warisan dari orang tuanya. Salah satu mantra yang biasa dia baca ketika melakukan ritual pada malam sebelum hariH, adalah: "Paranak Kiringet Ki Depo Hadir..." yang dibaca berkali-kali sampai jin yang dipanggil untuk menjaga si calon dan juga menjaga TPS datang, dan menuruti perintahnya. Menurutnya ada 4 jin yang akan menjaga 4 sudut TPS, yang diperintahkan oleh si dukun agar menjaga TPS dari magic yang digunakan oleh calon lain dan juga agar warga yang masuk ke dalam TPS dikaburkan pandangan dan pikirannya supaya selalu ingat wajah si calon (Dyt 2009).

Dari penjelasan di atas, jelas bahwa mantra bagi pelaku magic di Banten pun dianggap sebagai elemen penting dalam praktik magic. Bagi mereka, tanpa membaca mantra-mantra tersebut di atas, khasiat magic tidak akan berpengaruh bagi si calon. Ini artinya bahwa konsep mereka tentang mantra bisa mempertegas teori Malinowski bahwa magic adalah pusat dari semua aktivitas magic.

\section{Sumber magic untuk Pilkades}

Ada beragam sumber magic yang digunakan oleh para ahli magic di Banten. Ahli hikmah biasanya menggunakan beberapa kitab klasik (kitab kuning) sebagai sumber referensi mereka dalam mempraktikan magic. Di samping dari kitab-kitab tersebut, kadang-kadang mereka juga menggunakan beberapa amalan dan wiridan tertentu yang mereka dapatkan dari guru atau ustadz mereka yang tidak terdapat dalam kitab-kitab tersebut. Kitab-kitab hikmah ini berisi berbagai macam amalan, wafak, wiridan dan cara perhitungan waktu (petungan) untuk menentukan hari baik dan hari naas seseorang yang kesemuanya diyakini memiliki nilai magis. Di antara kitab-kitab klasik yang digunakan oleh para ahli hikmah untuk kepentingan magic adalah 1) Kitab Al-Awfaq karya Imam al-Ghazali; 2) Kitab Mambau Ushuli Al-Hikmah karya al-Imam al-Kabir wal Hakim Asy-Syahir Abi 'Abbas Ahmad Ibn Ali al-Buni; 3) Kitab Tahqiqu 'ala Sa'ati Al-Khair; 4) Kitab AsSiru al-Jalil; dan 5) Kitab Abu Ma'syari al-Falaki.

Dukun biasanya mendapatkan ilmu magicnya dari orang tua atau warisan yang diturunkan secara turun temurun. Sementara dukun lain, mengatakan bahwa dia mendapatkan sebagian besar ilmu magic dan peralatan-peralatan magicnya dari Nyi Roro Kidul dengan melakukan tirakat. Bpk. Bsn juga mengaku bahwa bapaknya, kakeknya, bapak dari kakeknya dan seterusnya juga seorang 
dukun. Jadi profesi dukun sudah dijalani secara turun temurun. Ada beberapa ilmu magic yang dia dapatkan dari orang tuanya (Bsn 2009).

\section{Pendapat informan tentang pengaruh magic terhadap pemenangan Pilkades}

Seseorang tidak mungkin mempraktikan magic kalau dia sendiri tidak yakin bahwa magic akan berpengaruh terhadap pasiennya. Begitu juga seorang calon kepala desa, tidak mungkin meminta bantuan dukun atau ahli hikmah agar membantunya dalam Pilkades dengan menggunakan kekuatan magic mereka, kalau dia sendiri tidak yakin bahwa ilmu magic yang dimiliki seorang ahli hikmah atau dukun yang dia datangi akan berpengaruh terhadap kesuksesannya dalam meraih kemenangan. Beberapa kepala desa yang berhasil diwawancarai mengaku tidak percaya dengan kekuatan magic ahli hikmah, apalagi dukun, apalagi bisa membuat mereka menang dalam Pilkades. Tetapi sebenarnya, itu hanya alasan yang mereka gunakan untuk menutup-nutupi bahwa mereka menggunakan magic dalam proses Pilkades. Hal ini barangkali karena mereka khawatir atau mungkin malu untuk mengakui bahwa mereka menggunakan dukun atau ahli hikmah untuk membantu mereka. Itu sama saja dengan membuka aib sendiri dan bisa menurunkan harga diri dan prestise mereka. Mereka selalu yakin bahwa mereka menjadi kepala desa, karena kemauan dan dorongan masyarakat. Berdasarkan beberapa informasi yang didapat dari beberapa dukun, ahli hikmah, warga dan beberapa orang yang pernah menjadi calon kepala desa atau yang pernah jadi tim sukses kepala desa maka didapat informasi kepala desa yang mana saja yang pernah mendatangi dukun atau ahli hikmah. Seorang dukun mengatakan bahwa kepala desa A dan B pernah dia bantu pada saat Pilkades, tapi ketika diwawancarai untuk dikonfirmasi apakah betul mereka datang ke dukun atau ahli hikmah, tidak satupun yang mengakui.

Dari penjelasan di atas jelas bahwa seberapapun besar keyakinan mereka, jelas mereka yakin bahwa sedikit banyak magic yang digunakan dalam proses Pilkades mempunyai pengaruh untuk kesuksesan Pilkades. Oleh karena itu, penggunaan magic dalam Pilkades dari dahulu sampai saat ini masih dipercaya oleh masyarakat. Ini mengindikasikan bahwa magic memang diyakini oleh pelaku dan bahwa magic punya andil dan pengaruh besar dalam pemenangan Pilkades. Dalam hal ini, beberapa ahli seperti Epton, Pyysianen, Kraig, dan Hutton menyatakan bahwa faktor keyakinan dan konsentrasi tinggi menjadi salah satu elemen penting yang harus dimiliki oleh pelaku magis. Jika elemen ini tidak dimiliki oleh si pelaku magis, maka efficacy magic hampir tidak mungkin terjadi (Epton 1974:112, Pyysianen 2004:72, Roheim 1955:21, Kraig 2005, dan Hutton 1948:211).

\section{Syarat dan pantangan dalam proses pemanfaatan magic untuk Pilkades}

\section{Syarat dan ritual yang harus dipenuhi}

Ada beberapa syarat dan ritual yang harus dijalani oleh calon kepala desa selama menggunakan magic dari ahli magic, di antaranya: a) ziarah ke makam Sultan Maulana Hasanuddin, makam para wali dan kiai, dan makam orang tua; b) puasa; c) ngamal atau Ngewirid; d) silaturahmi dan meminta do'a kepada orang tua, guru, kiai; e) menyantuni anak yatim; dan f) melakukan aktivitas sesuai petungan.

\section{Pantangan yang harus dihindari}

Selain beberapa persyaratan yang harus dilakukan oleh para calon kepala desa untuk memenangkan proses pemilihan kepala desa, ada juga beberapa pantangan yang tidak boleh dilakukan oleh para calon, di antaranya: a) berbuat zina; b) minum-minuman keras; c) durhaka kepada kedua orang tua; d) melanggar syarat-syarat dan ritual yang harusnya dipenuhi dan dijalani; e) tidak boleh mengambil kotak amal di kuburan; dan f) selama melakukan ngamal atau ritual wiridan, sampai penghitungan suara, si calon tidak boleh melewati (ngelangkahi) tali tambang yang digunakan untuk mengikat binatang, yang dalam kalimat Jawa Banten dinyatakan dengan 'aja ngelangkahi tampar sing ana satone, selagine ngamal'(Dyt 2009). 


\section{Pandangan masyarakat terhadap penggunaan magic dalam Pilkades}

Masyarakat Banten pada umumnya tidak melarang seseorang menggunakan magic selama itu untuk tujuan yang baik. Jika tujuannya untuk hal-hal yang buruk, apalagi digunakan untuk mencelakakan orang lain dengan menggunakan black magic semacam teluh dan tenung, mereka sepakat menolak dan menganggap itu sebagai kejahatan dan perbuatan melanggar norma agama dan norma sosial.

Beberapa kepala desa, mantan kepala desa dan mantan calon kepala desa yang berhasil diwawancarai, mengatakan sah-sah saja seorang calon menggunakan magic dalam proses Pilkada selama tidak merugikan dan mencelakakan orang lain. Dengan kata lain magic yang digunakanpun adalah jenis magic yang tidak melanggar aturan agama.

Sementara itu, beberapa kiai hikmah yang kami wawancarai pun sependapat dengan opini di atas. Mereka berargumen bahwa manusia harus berikhtiar bukan hanya secara lahiriah saja, tapi juga harus nyareat secara batiniah, karena kalau aspek lahiriah saja yang dipenuhi, sementara aspek batiniahnya tidak dilakukan, akan terjadi ketimpangan, dan hasilnya akan timpang. Mereka juga berpendapat, selama magic yang digunakan itu bersumber dari Al-Qur'an atau dari kitab-kitab hikmah, atau yang diberikan oleh kiai yang tentunya tidak melanggar ajaran Islam; menggunakan magic dalam proses Pilkades itu dibolehkan. Akan tetapi, K.H. Mfs, menolak pendapat mayoritas tersebut. Beliau berpendapat bahwa magic boleh digunakan pada kondisi-kondisi kritis atau darurat, seperti pada saat ada huru hara atau perang, seseorang boleh menggunakan wafak untuk keselamatan, tetapi kalau bukan dalam kondisi darurat, seorang Muslim tidak boleh menggunakan magic. Semuanya harus secara total diserahkan kepada Allah SWT.

Beberapa tokoh masyarakat di Kecamatan Ciomas dan Kecamatan Padarincang yang berhasil diwawancarai berpendapat bahwa sebenarnya mereka kurang setuju jika ada calon kepala desa yang memanfaatkan kekuatan magic untuk memenangkan Pilkades, karena proses Pilkades haruslah bersifat Langsung, Umum, Bebas dan Rahasia serta harus dilakukan secara demokratis. Tidak boleh memaksakan seseorang untuk memilih dirinya baik dengan cara menekan, mengintimedasi, mengiming-imingi uang, dan juga dengan cara-cara halus, seperti menggunakan magic, apalagi dengan menggunakan black magic yang jelas-jelas dilarang oleh agama.

Dari penjelasan di atas, jelas bahwa warga Banten khususnya di dua kecamatan, Ciomas dan Padarincang, memiliki persepsi berbeda tentang penggunaan magic dalam proses Pilkades ini. Sebagian setuju dengan alasan sebagai bentuk ikhtiar yang bersifat batiniah atau pun karena sudah menjadi tradisi dan budaya di Banten, sebagian lagi kurang setuju atau menganggap tidak pantas bahwa proses demokrasi di pedesaan harus dikotori dengan cara-cara yang tidak fair dan irrasional.

\section{Simpulan}

Dalam kehidupan politik lokal di Banten, sudah menjadi pengetahuan umum bahwa sebagian orang yang mau mencalonkan diri menjadi calon kepala desa, calon bupati, calon anggota dewan, bahkan calon gubernur mendatangi para kiai (kiai hikmah) baik untuk bersilaturahmi, meminta doa restu, meminta dukungan politis, bahkan meminta doa-doa atau wiridan atau mantra tertentu agar mereka berhasil dalam proses pemilihan. Tidak jarang mereka datang ke dukun-dukun yang dikenal memiliki kemampuan magic dan sudah memiliki reputasi baik dan banyak pengalaman dalam membantu para pejabat atau politikus yang ingin memenangkan pemilihan. Sekalipun secara rasional mereka yakin sudah memiliki pengikut dan jumlah pemilih yang banyak, tetapi mereka sepertinya belum yakin 100\% kalau mereka belum mendatangi kiai, ahli hikmah, dukun dan sejenisnya. Oleh karena itu, tidak jarang rumah-rumah para kiai hikmah yang punya reputasi tinggi dalam hal kepemilikan ilmu magi, pada waktu-waktu tertentu, terutama menjelang pemilu, pilkada, maupun pilkades akan ramai dikunjungi oleh orang-orang yang memiliki kepentingan politis. Tidak jarang, mereka akan memberikan hadiah yang besar kepada sang ahli magic ketika mereka betulbetul berhasil dalam proses pemilihan. 
Dari hasil penelitian lapangan, nampak bahwa sebagian besar calon kepala desa (untuk tidak menyebut seluruhnya) memanfaatkan kemampuan magic para ahli magic baik kiai, ahli hikmah, maupun dukun dan orang pintar (yang memiliki ahli magic) dalam proses pemilihan kepala desa. Ada berbagai jenis ritual dan formula magic yang digunakan oleh para ahli magic yang digunakan untuk membantu para calon kepala desa dalam memenangkan Pilkades. Bahkan, beberapa narasumber (kiai, ahli hikmah, dan dukun) menceritakan bahwa beberapa calon anggota dewan, bupati, gubernur, juga datang ke tempat mereka untuk meminta bantuan kemampuan magic mereka.

Dalam proses pemilihan kepala desa yang seharusnya bersifat demokratis dan menjunjung tinggi aspek kejujuran dan keadilan, praktik magic juga sudah dimanfaatkan oleh para calon untuk bisa memperoleh kemenangan dalam Pilkades. Tidak jarang calon kepala desa juga menggunakan dukun ilmu hitam untuk membantunya dalam pelaksanaan Pilkades.

\section{Daftar Pustaka}

Ahmad MA (2005) Ahli hikmat di Banten. Disertasi, UIN Syarif Hidayatullah, Jakarta.

Ali L (1998) Kamus besar Bahasa Indonesia. Jakarta: Balai Pustaka.

Bruinessen MV (1995) Kitab kuning, pesantren dan tarekat: Tradisi-tradisi Islam di Indonesia. Bandung: Mizan.

Bsn (2009) [personal communication] 12 Oktober.

Daenury M (2009) [personal communication] 12 November.

Dyt (2009) [personal communication] 5 Oktober.

Epton N (1974) Magic and mystics of Java London: Octagon Press.

Faturahman (2009) [personal communication] 10 Juli.

Hamilton M (2002) The sociology of religion. New York: Routledge.

Hananudin A (2009) [personal communication] 22 November 2009.

Hutton W (1948)Magic:A sociological study. London: Oxford University Press.

Kraig DM (2005) Modern magic: Eleven lessons in the high magical arts. Minnesota: Llewellyn Publications.

Malinowski B (1954) Magic, science and religion, and other Essays.New York: Doubleday, Anchor. Maqsud J (2009) [personal communication] 22 Oktober.

Mauss M (1972) A General theory of magic. New York: Routledge Classics.

MS (2009) [personal communication] 2 Juli.

Munawir (2009) [personal communication] 27 Juli.

Munji (2009) [personal communication] 28 November.

O'Keefe DL (1982) Stolen Lightning: The social theory of magic. New York:Continuum.

Pyysianen I (2004) Magic, miracles, and religion: A scientist's perspective. Oxford: AltaMira press.

Roheim G (1955) Magic and Schizophrenia.New Jersey: Prentice-Hall Inc.

Saepudin (2009) [personal communication] 22 Agustus.

Slmt (2009) [personal communication] 16 September.

Supriyadi A (2009) [personal communication] 15 Oktober.

Tia (2009) [personal communication] 13 Juli. 